\title{
火山灰中の鉱物からみた水蒸気噴火のメカニズム
}

\author{
大場 司* 井村 匠** 南 裕 介*** \\ シャレザ サイデイナ アンカサ****
}

\section{Mechanisms of Steam-blast Eruptions Inferred from the Mineralogy of Volcanic Ash}

Tsukasa OHBA*, Takumi IMURA**, Yusuke MINAMI***

and Syahreza Saidina ANGKASA ****

[Received 25 December, 2020; Accepted 1 April, 2021]

\begin{abstract}
Steam-blast eruptions are classified into three categories: (1) hydrothermal eruption caused solely by a phase change of hydrothermal water within a hydrothermal system; (2) phreatic eruption caused by a new thermal input derived from a magma body in a sub-volcanic aquifer; and, (3) ultravulcanian eruption (gas eruption), a type of vulcanian eruption, which is caused by gas degassed from magma accumulating under a lava plug. It is proposed that these can be classified from a petrological analysis of eruption products based mainly on the authors' previous contributions. Volcanic ash from hydrothermal eruptions is characterized by abundant altered lithics. At some composite volcanoes, altered lithics exhibit a wide variety of alteration types including siliceous, advanced argillic, phyllic, and potassic alterations, which are considered to originate from alteration zones of composite volcanoes. The association of alteration zones are correlated with those around porphyry copper deposits. The products of phreatic eruptions are composed mainly of strongly acid altered rocks, but may also contain fresh volcanic rock fragments. The rocks are derived from selectively/partially altered rocks under the crater. Ultravulcanian eruptions mainly release fresh lithic fragments and may also emit sulfur compound minerals (mainly sulfate), but the products contain no alteration minerals indicating hydrothermal acid leaching.
\end{abstract}

Key words : steam-blast eruption, hydrothermal eruption, ultravulcanian eruption, volcanic ash, alteration

キーワード : 水蒸気噴火，熱水性噴火，ウルトラブルカノ式噴火，火山灰，変質

\footnotetext{
* 秋田大学国際資源学部

** 山形大学理学部

*** 産業技術総合研究所

*****プルタミナ大学探査生産技術学部

* Akita University, Akita, 010-8502, Japan

** Yamagata University, Yamagata, 990-8560, Japan

*** National Institute of Advanced Industrial Science and Technology, Tsukuba, 305-8567, Japan

**** Faculty of Exploration and Production Technology, Universitas Pertamina, Jakarta, 12220, Indonesia
} 


\section{I. はじめに}

爆発的火山噴火は，その噴火メカニズムからマ グマ噴火，マグマ水蒸気噴火，水蒸気噴火に分類 される。マグマ噴火の爆発性はマグマ中の揮発性 成分（おもに水蒸気）に由来する一方，マグマ水 蒸気噴火と水蒸気噴火の爆発性は地下水などの外 来水に由来する。一般に，マグマ水蒸気噴火と水 蒸気噴火はマグマが放出されるか否かで区別され ている。水蒸気噴火（水蒸気爆発）という現象は 古くから報道を通して伝えられていたが，御猋山 2014 年噴火災害以降，この火山現象は改めて関 心を集めるようになった。水蒸気噴火を理解する ために, 地球物理学, 地球化学, 地質学, 岩石学・ 鉱物学的といった複数の手法による研究が現在も 進行している。地質学や岩石学・鉱物学的手法は 過去の噴火現象を解明することができ，数多くの 事例について扱うことができる。これは地球物理 観測や地球化学観測が現在進行中の現象を対象と しているのとは対照的である。とくに岩石学・鉱 物学的手法は火山の地下の構造や現象を理解する ために有効な手法であるため，噴火メカニズムの 解明には重要である。著者らは水蒸気噴火噴出物 について岩石学および鉱物学的調査をおこない, 水蒸気噴火の発生メカニズムや噴出物の起源を 探る研究を行ってきた（Ohba and Kitade, 2005; Ohba et al., 2007: Minami et al., 2016; 井村ほか, 2019a; Imura et al., 2019b)。その経験に基づき, 国内外の関連研究の知見も加えつつ，本論前半で は水蒸気噴火の発生メカニズムについて論ずると ともに，その用語に関する問題点を考察する。本 論の後半では，水蒸気噴火の発生メカニズムを 3 つに分類し，それぞれが岩石学的・鉱物学的特徵 とどのように関連しているかについて，最近の研 究成果をもとに紹介する。

\section{II. 水蒸気噴火発生メカニズムと用語}

\section{1）水蒸気噴火の定義}

荒牧（1996） は水蒸気噴火を「高温高圧の水 蒸気の作用で起こる爆発的な噴火活動」として いる。その水蒸気の起源にも言及しており，「水
蒸気はマグマから分離して地下の空隙にたくわ えられた場合もあれば，地下水がマグマに熱せら れて高温高圧になる場合もある」とし，後者の英 訳が phreatic eruption であると明言している。 最近「水蒸気噴火」という語が用いられる際に は，必ずしもこの荒牧（1996）の定義が尊重さ れず, phreatic eruption と水蒸気噴火は同義語, すなわち唯一の訳語とみなされることが多い。と くにニュースやウェブサイト上での一般向け解 説では，地下水がマグマに熱せられる phreatic eruptionのモデルのみが水蒸気噴火のメカニズ ムとして示されることが多い。このように用語の 定義と現象解釈に齟炡があるため，われわれはこ の傾向には問題があると考えている。

気象庁は同庁ウェブサイト上の火山用語集にて 水蒸気噴火を「火山の地下にある水が加熱され， または減圧により，急激に水蒸気となって膨張す ることを駆動力とする噴火のこと」と定義してい る（気象庁ウェブページ “噴火に関する用語”）。 この定義は一部荒牧（1996）の定義と一致して いるが，異なる部分もある。火山の地下にある水 が減圧に伴って爆発する現象は荒牧（1996）の 定義に含まれていないが，地下空隙に蓄積した高 温高圧の水蒸気による爆発は気象庁の定義に含ま

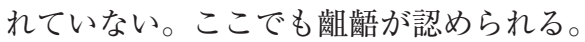

このように，水蒸気噴火という語が使用される 際に，用法が統一されていない。荒牧（1996） と気象庁の定義はいずれも水蒸気噴火の発生メカ ニズムに関わるものであるため，水蒸気噴火の発 生メカニズムについて統一的な見解が得られてい ないともいえる。水蒸気噴火に対する定義が専門 家ごとに異なっていては，火山防災にも深刻な影 響を及ぼしかねず，整理が必要である。そこで， 本論では荒牧（1996）と気象庁の定義に基づき, 水蒸気噴火の発生メカニズムの説明と併せて用語 について議論する。

ある噴火が水蒸気噴火であると判断する際，火 山灰構成粒子の観察結果を根拠とすることがあ る。この場合, 火山灰中に本質物質（新鮮なマグ マ片）が含まれなければ水蒸気噴火とみなされる。 しかしながら，本質物質を含まないという事実が， 


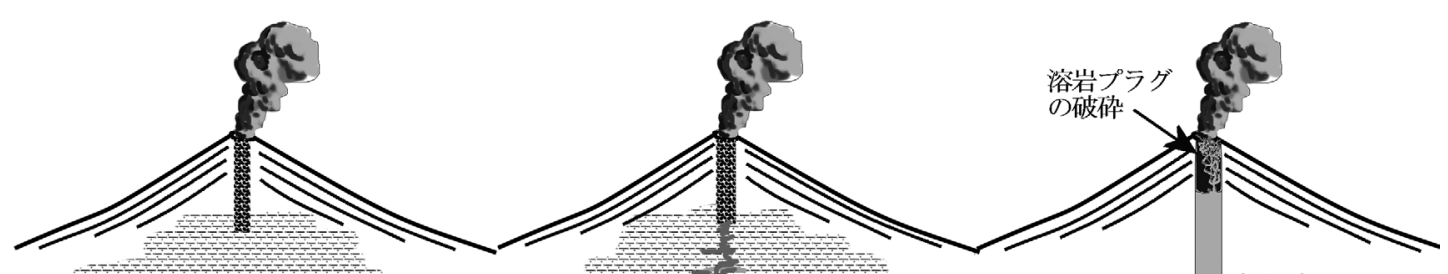

带水層

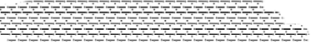

(a)

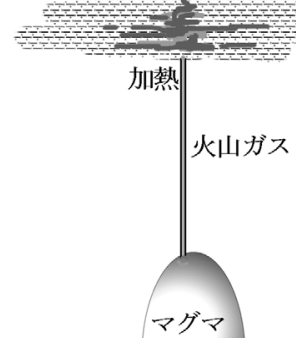

(b)
火山ガス

带水層
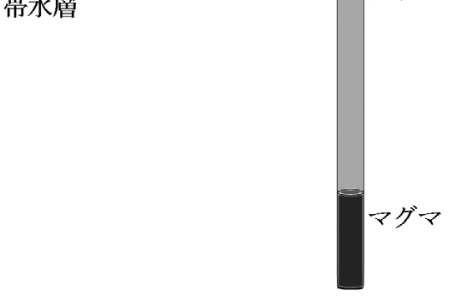

(c)

図 1 水蒸気噴火の 3 つのメカニズム.（a）hydrothermal eruption. 熱水系の熱エネルギーのみに由来する爆発的噴 火.（b） phreatic eruption. 地下水がマグマからの熱によって加熱されて生じる爆発的噴火. (c) ultravulcanian eruption. ブルカノ式噴火の一種. 溶岩の下に蓄積した火山ガスによる爆発的噴火. 固結した火道上部溶岩プラ グが破砕する。

Fig. 1 Three mechanisms of steam-blast eruptions (Suijoki Funka): (a) hydrothermal eruption, an explosive eruption solely derived from the thermal energy of a hydrothermal system; (b) phreatic eruption, an explosive eruption caused by magma heating groundwater; and, (c) ultravulcanian eruption, a kind of vulcanian eruption. A solid lava plug at the top of a vent exploding, which is caused by high-pressure volcanic gas.

地下水がマグマによって熱せられるという現象の 直接的証拠にはならない。すなわち，本質物質の 不在のみを根拠として phreatic eruption である とは断定できないのである。それでは，火山灰中 に本質物質を含まない噴火は，どのような機構に より生じるのだろうか。ここでは，おもなメカニ ズムとして，1）地熱流体の突沸，2）マグマか らの新たな熱による地下水の加熱，3）マグマか らのガスの蓄積の 3 つをあげる（図 1 )。その理 由は，荒牧（1996） と気象庁の定義を網羅する ためである。気象庁の定義に含まれる地下水の減 圧による水蒸気噴火は，1）地熱流体の突沸に相 当する。すなわち，過熱水が減圧によって突沸す る現象である。2)のマグマからの新たな熱による 地下水の加熱による水蒸気爆発は, 荒牧（1996） および気象庁のいずれの定義にも含まれる。マグ マからの熱によって地下水が高温になり，爆発に 至る現象である。3)のマグマからのガスの蓄積 は荒牧（1996）の定義にのみ含まれ，相転移を
伴わず，気相が地下に蓄積して高圧になり爆発す る現象である。

\section{2）3つの発生メカニズムと用語}

\section{2-1）地熱流体の突沸}

地熱流体の突沸が原因となる噴火は，英語では hydrothermal eruption (Browne and Lawless, 2001)，もしくは boiling point eruption (Mastin, 1995）と呼ばれる。日本語の噴気爆発（湯原, 1997）や熱水性爆発（八幡ほか, 1994）がこれに あたる。Browne and Lawless（2001）は高温地 熱流体の熱損失と相変化のみに由来する噴火を hydrothermal eruption であるとし，マグマによ る加熱を伴う phreatic eruption とは明確に異な るものとしている。一方, Barberi et al. (1992) は, hydrothermal eruption も含めて地下水の相 転移による爆発的噴火をすべて phreatic eruption と呼ぶことを提唱している。日本でも後者の定義 に従うことがある（及川ほか, 2018）。噴火が地 熱流体のみに由来するのか，マグマによる加熱が 
関与したのかを，本質物質の有無のみから判断す るのは容易ではない。そのため両者を区別しない という立場もあり得る。しかしながら，新たなマ グマ貫入イベントと噴火が関連しているか否かは 火山防災上本質的な問題であるため，両者の区別 は時として重要である。

\section{2-2）マグマからの新たな熱による地下水の加} 熱

マグマによって地下水が加熱されて生じる爆発 的噴火は，一般に phreatic eruption とされる。 Browne and Lawless（2001）は噴火エネルギー がマグマからの熱のみに由来する場合を phreatic eruption としている一方, 前述の通り Barberi et al.（1992）による広義の phreatic eruption は, マグマによる加熱を伴わない噴火（hydrothermal eruption）も含む。前述の hydrothermal eruption は，熱水があらかじめもっていたエネルギー だけで爆発するというものである。ところが，火 山の熱水系では，一般に熱水がもつ熱エネルギー そのものが過去のマグマに由来している。それは 噴火直前に貫入したマグマの場合もあれば, 数年, 数百年，あるいは 100 万年前に地下に定置した マグマということもあり得る。より明確に hydrothermal eruption と phreatic eruption を区別す るのはあれば，マグマ（およびマグマからの火山 ガス）に由来する急激な熱エネルギー変化による 爆発的噴火が phreatic eruption とみなすのがよ いだろう。ただし，この「急激」が，どの程度の 時間スケールであるかについては検討が必要であ る。

Browne and Lawless (2001)は phreatic eruptionでは地下水が十分に「冷たい」必要がある としている。実際には，活火山の火口下には高温 の熱水系が発達している場合が多く，ある程度高 温の地下水（熱水）がマグマによって加熱されて 生じる爆発的噴火も phreatic eruption とされる ことが多い。例えばコスタリカのトゥリアルバ火 山などの噴火事例をまとめた Stix and de Moor （2018）の研究がある。彼らは, phreatic eruption を phreato-vulcanian (タイプ1) と phreatosurtseyan（タイプ 2 ）に分類し，いずれもマグ
マから分離した火山ガスが地下水の加熱に寄与し ていると考えている。そのうち phreato-vulcanian 噴火をもたらす地下水は，火口下の地下で熱水系 を形成しているものとしている。すなわち，元の 地下水温度とは関係なく，マグマもしくはマグマ から分離したガスによって地下水が加熱されて生 じる噴火を phreatic eruption としている。

\section{2-3） マグマからのガスの蓄積}

これは地下の空隙にたくわえられたマグマ由来 の火山ガスによる爆発的噴火である。荒牧 (1996) による水蒸気噴火の定義はこの夕イプの噴火を含 んでいる。英語の gas eruption（Mastin, 1995), ultravulcanian eruption (MacDonald, 1972; Lookwood and Hazlett, 2010）にあたる。水から 水蒸気への相変化を伴わないことから, Browne and Lawless (2001)の定義はもとより，Barberi et al.（1992）による広義の phreatic eruption に も含まれない。したがって，水蒸気噴火ではある ものの, phreatic eruption とするのは好ましく ない。Lookwood and Hazlett（2010）はこの噴 火をブルカノ式噴火の一種と見なし，固結した溶 岩の破片のみを灭山灰として噴出する噴火である としている。

\section{3) 水蒸気噴火とその英訳について}

ここまで述べたように，水蒸気噴火とその英訳 に関する用語の使い方は単純ではない。現在普及 している用法を尊重するならば，日本語としては， hydrothermal eruption を含め本質物質を含まな い噴火をすべて水蒸気噴火と呼ぶのが現実的と考 えられる。ただし，この語を使用する際は，水蒸 気噴火の発生メカニズムは多様であり，地下水が マグマに加熱されて生じる phreatic eruption だ けではないということを明確にすべきである。そ れでは，水蒸気噴火の英訳としては何が適切だ ろうか。成因に応じて hydrothermal eruption, phreatic eruption, ultravulcanian eruption を使 い分けるという方法もあるが，煩雑である。その 他に，水蒸気噴火にもっとも近い意味をもつ英 語として steam-blast eruption（Jaggar, 1949; Barberi et al., 1992; Mastin, 1995）がある。こ れは水蒸気の膨張に伴う爆発的噴火に対するもっ 
とも一般的な表現である。成因がはっきりしない 水蒸気噴火の訳語としては, これが最適であろう。

著者らはこれまで，水蒸気噴火の噴火メカニズ ムを理解するために火山灰の岩石学的研究を行っ てきた。次章より，これまでに報告された水蒸気 噴火火山灰の岩石学的な事例研究をもとに, 上で 述べた水蒸気噴火のメカニズムと関連づけて考察 する。

\section{III. 地熱流体の突沸}

火山の地下には熱水系が存在することが多く, 地熱流体の突沸による hydrothermal eruption は頻繁に生じると考えられる。それらを phreatic eruption と区別するには，噴火エネルギーがマ グマによる加熱に直接起因しないことを示す必要 があるが，それはきわめて困難である。マグマに よって新たに加熱されていないことを証明するの は事実上不可能だからである。それでも火山防災 上は，マグマによる熱的関与の有無は噴火推移予 測のうえで重要であるため, できるだけ両者を区 別したい。そのためには，観測からはマグマ関与 の痕跡が一切検知できず，かつその噴火の原因が 既存の地熱流体の沸騰だけで説明できるような場 合（例えばニュージーランド，ロトルア市内で断 続的に発生する噴火や後述の秋田焼山 1997 年の 一連の噴火）は, hydrothermal eruption と見な すのが現実的である。この種の噴火は地下浅所の 熱水系に由来することが多いが，複成火山の中央 火口で発生する hydrothermal eruptionのなか には，複数の変質帯に由来し，互いに異なる鉱物 組み合わせをもつ火山灰が放出する例がある（大 場, 2011)。このような場合の鉱物組み合わせは, 金属鉱床学や地熱地質分野で提唱されている複成 火山下の変質帯モデルと調和的である（図 2 )。

Hydrothermal eruptionの例としてあげられ るのは，1997 年 5 月に秋田焼山で発生した澄川 温泉地すべりに伴う水蒸気噴火である。この例 は，地すべりに伴い，温泉地下浅所に存在した熱 水の気化が進行して爆発したものである（塚本, 1997）。この水蒸気噴火で放出された火山灰は熱 水変質物に富んでおり，モンモリロナイトなど比

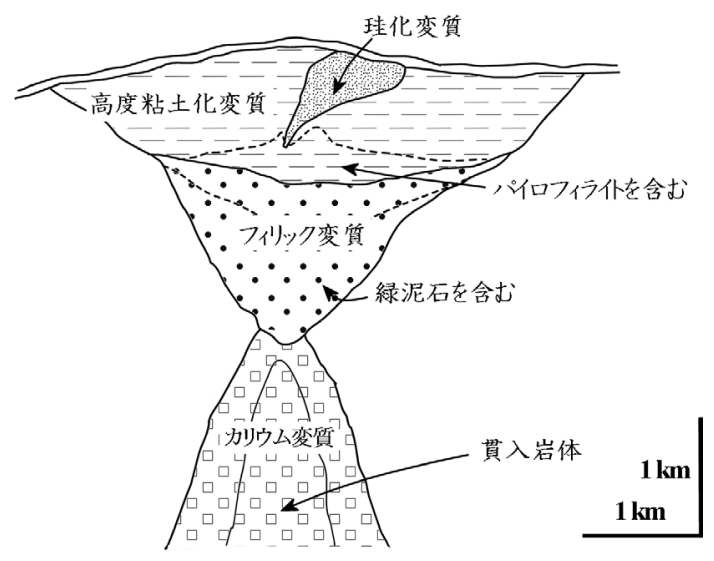

図 2 斑岩銅鉱床周辺地質等の知見に基づく複成火山 直下に発達する熱水変質帯モデル（Sillitoe, 2010 を一部改変).

Fig. 2 Model of alteration zones developed under composite volcanoes proposed from observations of the geology around porphyry copper deposits (modified from Sillitoe (2010)).

較的低温の中性〜アルカリ性熱水を示す熱水によ る変質を示す鉱物が含まれる（伊藤ほか, 1997）。 これらは澄川温泉の地下浅所熱水系で生成した鉱 物である。地すべりに伴う急減圧によってこの浅 所熱水系を構成する過熱水が突沸し爆発した可能 性が高い。

澄川温泉地すべりの約 3 ケ月後の 8 月 16 日に, 秋田焼山火山の中央火口内にて水蒸気噴火が発生 した。この噴火も hydrothermal eruption であ ると考えられる。これは山体深部熱水系に由来 し，深所～浅所の複数の変質帯に由来する火山灰 を含む例の 1 つである。Ohba et al. (2007) は, この噴火の火山灰分析や目撃談をもとに，山体深 部から高温酸性熱水が上昇し，ごく浅所にて爆発 したことを解明した。深部熱水系から上昇した原 因は解明されていないが, 上方への水圧破砕に よって熱水が地表へ到達したものと考えられる。 深部熱水系からの水圧破砕の開始は，地震による 上盤岩石の破壊等が原因となり得るため，マグマ による加熱を必要としない。火山灰の主体は著し く酸性変質した岩石の破片である。深部（深さ約 $1 \mathrm{~km})$ ～地表付近までの多様な深度に由来する変 


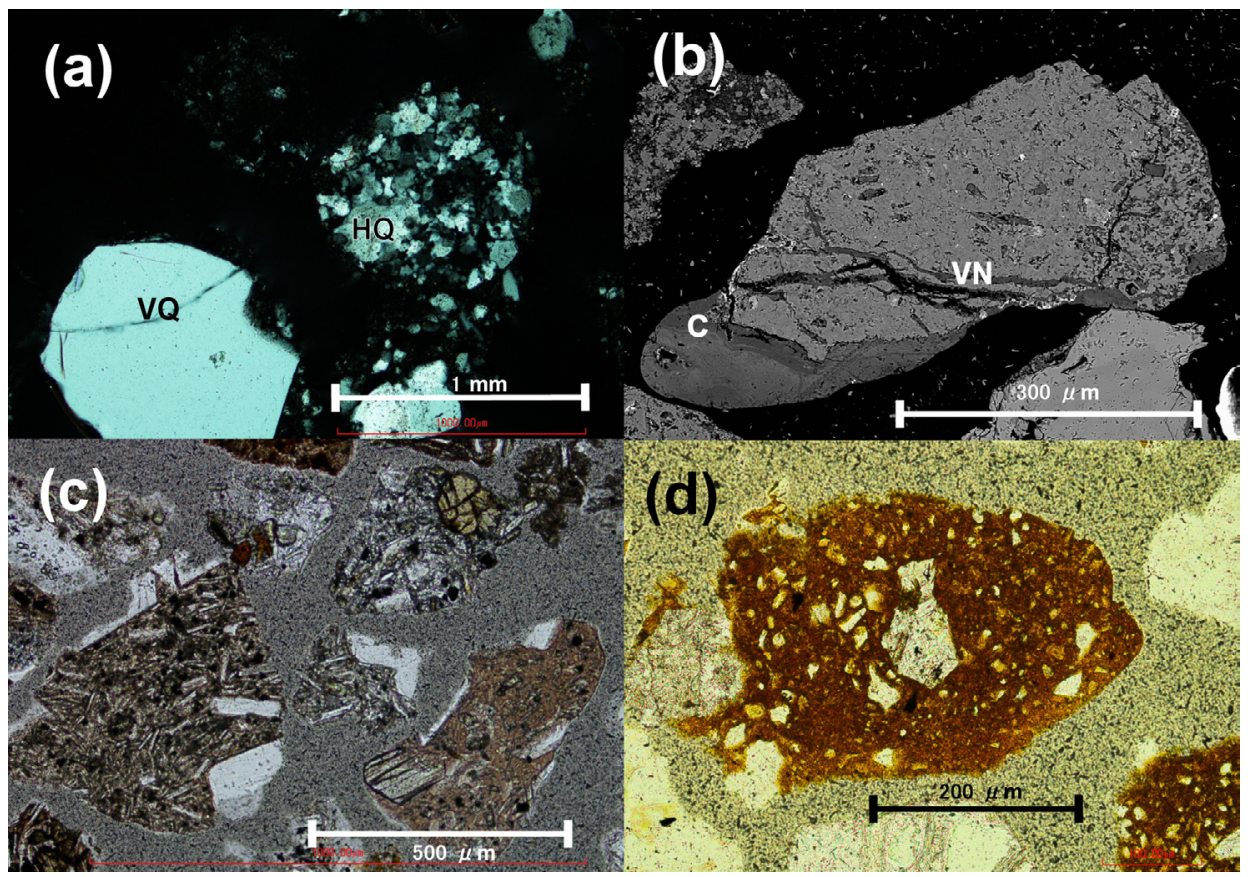

図 3 代表的な水蒸気噴火火山灰.（a）1997 年秋田焼山水蒸気噴火の火山灰. 右は珪化変質由来の火山灰（HQ）。左 は地表に分布するデイサイト溶岩ドーム由来の石英 (VQ).（b）十勝岳火山噴出物中の部分変質火山灰 (中央). 明灰色部分は新鮮な結晶質火山岩であり，長石や輝石からなる。暗い部分はシリカ鉱物からなる変質部であり， コロフォームまたは層状の珪化部 (c), 脈状シリカ（VN）が特徵的である. (c) 鳥海山の完新世テフラ層の 1 つ. 未変質の高結晶度火山岩片からなる。（d）鳥海山の完新世テフラに含まれる火山豆石．基質部は非晶質含鉄ア ルミナ珪酸塩，ミョウバン石，塩化物からなる.

Fig. 3 Representative ash particles from steam-blast eruptions. (a) Volcanic ash from the 1997 Akita-Yakeyama eruption. The right particle (HQ) is an ash particle of siliceous altered rock. The left particle (VQ) is a quartz crystal derived from the dacite lava dome on the surface. (b) Partly altered volcanic ash (center). Bright grey part consists of unaltered crystalline volcanic rock containing feldspar and pyroxenes. Dark gray area is alteration part consisting of silica mineral. Alteration in this particle is characterized by colloform or layered (c) and veinlet silica (VN). (c) Sample from a Holocene tephra layer from Chokai volcano. Ash is composed of unaltered crystalline volcanic rock. (d) Accretionary lapillus from a Holocene tephra layer from Chokai volcano. Matrix consists of amorphous Fe-bearing alumino-silicate, alunite, and chloride.

質岩を含み，低温で弱酸性〜中性を示すスメク夕 イト変質，酸性流体による珪化変質や高度粘土化 変質が認められる。図 $3 \mathrm{a}$ はこの噴火の火山灰の 写真であり，右の珪化変質火山灰粒子が噴出物中 でもっとも多く含まれる火山灰である。高度粘土 化変質火山灰は，シリカ鉱物とカオリン鉱物を主 体とするが，これに加えて地表の変質帯には認め られないパイロフィライトや紅柱石を含む変質岩 も含まれる。これらは深所からもたらされたもの と考えられる。この火山灰には，火山ガラスを含
む新鮮なデイサイト質火山灰が含まれる。このデ イサイト火山灰の起源は, 火山ガラス組成等の岩 石学的類似性より, 火口周辺に分布する溶岩ドー ムであるとされている。また，変質物由来ではな い石英結晶が含まれるが，これも溶岩ドームのデ イサイトに含まれる石英斑晶に由来するものであ る(図 $3 \mathrm{a}$ 左の火山灰)。

御猋山 2014 年噴火の発生原因については現在 も議論が続いている。火山灰中の変質物を研究 した Minami et al. (2016) およびImura et al. 
（2019b）は，この噴火を hydrothermal eruption であるとしている。変質鉱物組み合わせが多様で あり，鉱床学で用いられる変質分類（水田・石山, 2009）にあてはめると, 珪化変質, 高度粘土化 変質, フィリック変質, カリウム変質が認められ る。この例も火山体深所から浅所まで複数の変質 帯を通って噴火したものと考えられる。この噴火 の火山灰の変質物の多様性は, 斑岩銅鉱床周辺の 変質分帯に対比できる。斑岩銅鉱床変質帯の一 般的地質構造モデルは, 過去の複成火山の地下 構造を表しているとされる（Sillitoe, 1973; 石原， 1992)。そこで, Minami et al. (2016) はこ れらの地質構造モデルと火山灰の変質を比較し て，大まかな深度を考察している。Imura et al. (2019b) も御猋山 2014 年噴火火山灰中より, 斑岩銅鉱床にも特徵的に産するミョウバン石族の APS (Aluminous phosphorous sulfate) 鉱物を 発見し, Minami et al. (2016) の結論を支持し ている。したがって, 御訔山 2014 年噴火は斑岩 銅鉱床を形成するような複成火山下の大規模熱水 系の流体に起因する噴火であることは確かである。 Ikehata and Maruoka（2016）もこの噴火が火 山下の熱水系に由来することを示し，更に火山灰 の硫黄同位体組成分析值から，山体内の熱水系内 にて同位体不均化反応が $270-281^{\circ} \mathrm{C}$ で生じたと 結論づけている。また, 1974 年と 2014 年噴火 の間で熱水系に大きな違いが認められないことも 結論づけている。一方 Miyagi et al. (2020) は, 少量の新鮮な火山岩片およびガラスからなる火山 灰を見いだし，その起源は 2007 年のマグマ貫入 イベントに関連していることを結論づけ，これを 2014 年噴火の熱源としている。

これら 3 つの例では, 熱水変質物が主要な構成 物である。石英等のシリカ鉱物，カオリン鉱物な どの含水アルミナ珪酸塩鉱物，ミョウバン石等の 硫酸塩鉱物を含むことが多く，他に白雲母，緑泥 石，力リ長石，沸石等の珪酸塩鉱物，黄鉄鉱，黄 銅鉱，閃覀鉛鉱，硫砣銅鉱などの硫化鉱物も見い だされることがある。これらの変質物とともに, いずれの例でも新鮮な火山灰も見いだされている。 1997 年澄川温泉地すべりに伴う水蒸気噴火と同
年秋田焼山 8 月噴火で見いだされたガラス質火 山灰は，いずれも既存の岩石や火山灰を取り込ん だものである。一方，御訔山 2014 年噴火噴出物 から見いだされた新鮮な火山灰は，2007 年に貫 入したマグマ由来の本質物質とされる。いずれの 場合も，化学分析や既存岩との対比といった岩石 学的な調査を詳細に行って結論を導いている。新 鮮な火山灰が含まれているか否かは容易に判定で きるものの，それらが本質物質であることを認定 するのはしばしば容易ではない。

\section{IV. マグマによる地下水の加熱}

マグマによる地下水の加熱には，マグマから の火山ガスが重要な役割を果たす（Stix and de Moor, 2018)。火山ガスが地下水と混合したり, 火山ガス自体が凝縮して液体になったりすると, 酸性熱水を生じる。そのような酸性熱水が岩石と 高温で反応すると, 著しい溶脱反応を生じる。こ のような反応では, 溶脱珪化変質が生じる。また, そのような熱水は硫酸成分に富んでおり，ミョウ バン石や石膏等の硫酸塩鉱物の生成を伴う。この 変質では，高度粘土化変質も伴う。したがって， このタイプの噴火による火山灰には珪化変質岩, 硫酸塩鉱物, 高度粘土化変質岩が含まれることが 期待される。しかしながら，これらの変質帯は前 述の成層火山内部の大規模熱水系に普通に存在す る。そのため既存熱水系に由来する hydrothermal eruption でも新しいマグマ（または火山ガ ス）の加熱による phreatic eruptionでも，変質 に要した時間が十分であれば同じ変質鉱物がもた らされる。したがって変質鉱物の生成速度が速け れば鉱物組み合わせだけで hydrothermal eruption か phreatic eruption かを区別することは困 難である。

頻繁にマグマが浅所に貫入し，新鮮な火成岩体 が繰り返し形成するような火山であれば，たとえ マグマ貫入時に酸性熱水による変質が生じたとし ても, 選択的変質（特定の相が变質し，他の相は 未変質のまま）または局部変質（空間的に一部の み変質し，他の部分は未変質）にとどまり，火口 の地下に新鮮な岩石が残存している可能性があ 
る。一方, 火口下に定常的な酸性熱水系が発達す る場合は, 長期間にわたって変質が進行するため, 広範囲に浸透した変質となることが期待される。 このような変質では源岩を構成する相が完全に消 失して変質鉱物のみになっている（ここでは強変 質と呼ぶ)。前出の秋田焼山 1997 年噴火火山灰 の変質岩には，局部変質や選択的変質は稀である 一方，強変質が主要であり，後者の例といえるだ ろう。井村ほか（2019a）はそのような観点に基 づき，十勝岳完新世の変質物に富む火山灰につい て調査を行った。井村ほか (2019a) は火山灰粒 子内に選択的変質や局所変質が認められるものを 弱変質火山灰とし, 強変質火山灰と区別してい る。十勝岳の水蒸気噴火火山灰は, 比較的変質が 進んでいない岩石由来の火山灰が多く含まれ，弱 変質火山灰が圧倒的に多い。未变質火山灰も一定 量含まれる。弱変質火山灰中では変質部分と新鮮 な岩石が残存する部分が共存する（図 $3 b ） 。$ 変質 部はシリカ鉱物およびミョウバン石が卓越する。 これらの鉱物は，溶脱珪化変質，硫酸酸性熱水か らの沈殿による付加変質, 斜長石の交代作用によ るものである。1926 年噴火（大正噴火）噴出物 については, Takahashi and Yahata (2018) も 同様の変質鉱物組み合わせを見いだしている。彼 らは変質鉱物組み合わせと硫黄同位体組成から, 深部からのマグマ性流体に由来する変質作用が生 じていると報告している。また, Takahashi and Yahata（2018）は，十勝岳火口近傍に地質構造 スケールで不均質な変質が進行していることも報 告している。この不均質な変質は, 溶岩と火砕物 の地層境界に沿った流体通路と関係している。

Takahashi and Yahata（2018）が見いだした不 均質な変質や，井村ほか $(2019 a)$ にるる顕微鏡 スケールでの変質の不均質性から, 十勝岳では, 酸性熱水による変質作用が広範に浸透した強変質 に至らず，局所的な状態にとどまっているといえ る。長期間の反応では部分変質・選択的変質より も広範の強変質が卓越すると考えられることか ら，火山性流体と火山岩との反応が短時間で終了 しているものと解釈される。この反応のタイムス ケールを推定するのは難しいものの，野上・吉田
（1993）による岩石-酸性熱水反応実験と微小又 ケールでの変質の不均質性の比較により, 井村ほ か（2019a）は数日またはそれより短時間である 可能性を示している。また，噴火前のどの時点で 反応が起きたかなど，反応と噴火の時間関係を解 明することも，水蒸気噴火のメカニズムを解明す る上で重要である。この点は現段階では解明でき ておらず，今後の課題といえよう。

マグマが頻繁に貫入して新鮮火山岩体を地表や 地下に形成するような火山であれば，選択的・局 所的な変質組織が生成しやすい。マグマ噴火の頻 度が比較的高い十勝岳はその代表的な例であろう。 火山灰粒子の多くがそのような局所的な変質を 被っているということは，短期間の岩石一酸性熱 水反応を経て噴火に至ったことを示している。す なわち, Stix and de Moore (2018) の phreatovulcanian の噴火メカニズムと合致する現象が起 きていたと考えるのが自然である。

Angkasa et al. (2019) は, インドネシアジャ ワ島のタンクバンパラフ火山の火山灰の構成物と 組織を観察し，過去数千年間の噴火様式の推移と 噴火過程を解明した。この火山に産する火山灰は 変質物に富んでいるが，新鮮なガラス質火山灰も 含まれる層が多い。水蒸気噴火とマグマ水蒸気噴 火を繰り返しており，頻繁に浅所へマグマが貫入 するようである。タンクバンパラフ火山の中央火 口であるラトゥ火口の内部は著しく変質作用が進 んでいる上に，噴気や噴騰といった熱水活動が活 発である。完新世の噴火はこの火口内で発生して おり, 浅所の酸性熱水が水蒸気噴火やマグマ水蒸 気噴火に関与しているようである。マグマ水蒸気 噴火は，大規模な酸性熱水系内にマグマが貫入す ることで発生している。水蒸気噴火も繰り返され ているが，そのなかには火口下の熱水系起源の hydrothermal eruptionも含まれる可能性があ る。一方，噴火前に火山性地震や膨張などの明確 な前兆現象があることから，水蒸気噴火の多くも マグマの貫入イベントと関係しているようである。 この火山の火山灰は, 強変質岩火山灰, 新鮮火山 灰，弱変質火山灰が混在しており，十勝岳よりも 強変質火山灰が卓越する。これは定常的な酸性熱 
水系が火口下に存在するためである。強変質火山 灰は珪化岩が卓越する。

タンクバンパラフ火山の水蒸気噴火の場合，定 常的な熱水系に由来する酸性の強変質火山灰が 特徵的であるため，火山灰の鉱物学的特徵から phreatic eruption と hydrothermal eruption を区 別するのは難しい。前章で紹介した御嶽山 2014 年噴火でも同様の問題がある。十勝岳では火口直 下に定常的熱水系があまり発達していないようだ が，タンクバンパラフ火山や御嶽山では定常的熱 水系が発達し，それが過去のマグマおよびそのマ グマ由来の火山性流体を起源とするために，最新 のマグマ由来の変質と似通ったものになる。直前 に貫入したマグマの影響を推定するには，例えば， 火山灰に付着した水溶性成分中の硫黄同位体分析 のような別の方法を用いるとよいだろう。

\section{V. マグマからのガスの蓄積}

マグマからのガスの蓄積による爆発的な噴火 は，火道に溶岩プラグが生成する環境で典型的に 発生するため，ブルカノ式噴火を生じる火山で発 生しやすい傾向がある。日本では，浅間山でこの 様式の噴火（1935-1941 年噴火）の報告がある (Minakami, 1942)。著者らはこのタイプの水蒸 気噴火の火山灰を詳細に調査した経験はないが, ブルカノ式噴火の火山灰の岩石学的研究が活動的 な火山にて盛んに行われており，それらが参考に なる。エトナ火山や桜島火山の火山灰に対しては 結晶度や形態に注目した研究がおこなわれ，噴火 様式および火山灰の起源との対応が議論されてい る (Taddeucci et al., 2004; Miwa et al., 2013)。 ブルカノ式噴火を特徵づけるのは，火道上部の固 化プラグの破砕により生成される高結晶度でブ ロック状の火山灰である。これに加え，火山ガラ スに富むスコリアやシデロメレーンを含むことが 多い。これらは流動形態などを呈し，液体のマグ マが噴出したことを示す。ブルカノ式噴火噴出物 は，低結晶度流動形態の火山灰と高結晶度ブロッ ク状の火山灰が混じり合って産し，その比率は幅 広く変化する。極端な場合では低結晶度流動形態 火山灰が不在で，高結晶度ブロック状火山灰のみ
から構成される場合もある。これは液体のマグマ が噴出せず，高圧ガスにより破砕した火道プラ グ由来の火山灰だけが放出される噴火である。 Miwa et al. (2013) は桜島の火山灰を観察し, 一連の活動の間に低結晶度の火山灰と高結晶度の 火山灰の比率が変化することを報告している。そ のなかには，マグマ由来火山灰のほとんどが高結 晶度ブロック状火山灰の噴火もある。エトナ火山 でも，高結晶度のタキライト質火山灰が優勢な噴 火があり，プラグの破砕に由来するものと考えら れる（Taddeucci et al., 2004）。すなわち，これ らの噴火では流動的なマグマが噴出せず，ほぼ固 体の破砕物のみが噴出すると見なせる。このよう な噴火をウルトラブルカノ式とすることができる が，同時に水蒸気噴火とみなすことも可能である。

図 $3 \mathrm{c}$ は鳥海山の完新世のテフラ層試料の薄片 写真である。新鮮な火山岩片からなる火山灰粒子 がこの試料の大部分を成している。この火山灰は ほとんど変質しておらず，熱水変質の影響を受け ていない。結晶度が高く, 発泡は悪い。一般にブ ロック状の形態を示す。本質マグマと判断できる ようなガラスに富む新鮮火山灰ではないことから， このような火山灰は水蒸気噴火（ウルトラブルカ ノ式噴火）に由来すると考えられる。熱水との反 応の痕跡が認められないことや，新鮮な固結火山 岩が破砕した火山灰が優勢であることから，マグ マからのガスの蓄積による爆発的噴火に由来する 可能性が高い。

桜島のブルカノ式噴火の火山灰には，高結晶 度の火山灰のほかに，“変質火山灰”が含まれる (Miwa et al., 2013)。また，エトナ火山のストロ ンボリ式・ブルカノ式噴火でも高結晶度の夕キ ライトのほかに, 石質岩片が含まれている（Taddeucci et al., 2004)。これらの研究では石質岩片 は母岩が破砕した火山灰とみなされ，火道上部の ほぼ固結したプラグ由来の火山灰とは区別される。 石質岩片の定義は研究者によって異なっており， もっとも一般的に用いられる用法は，発泡が悪く 密度が高い異質な火山灰である。しかし，ブルカ ノ式噴火の研究では発泡が悪く密度が高い火山灰 も本質物として扱うため，特別な定義が必要とな 
る。Miwa et al.（2013）の例では，明らかに変 質を被っている石質火山灰を本質物と区別してい る。玄武岩質マグマ噴火の火山灰について，火口 内に堆積後にリサイクルされた火山灰を全て石質 岩片として扱い，表面組織の違いから本質物と区 別している例もある（D’Oriano et al., 2014）。

変質に着目する場合，その成因解釈には注意が 必要である。変質の有無は岩石の新旧の決め手に はなるとは限らない。変質とは流体との反応がど れほど進んだかという指標にはなるが，すべての 岩石が流体と均等に反応しているという仮定は無 理があり，したがって，古い母岩に由来する火山 灰が変質しているとは限らず，逆に新しい岩体で も高温の流体に短時間曝されただけで変質するこ ともあるだろう。古い岩石が未変質もしくは微弱 な変質しか被っていない場合，新しい火道プラグ の岩石と同一の岩石組織を示す可能性があるの で，そのような火山灰の起源を論ずる場合は注意 が必要であろう。

このタイプの噴火による変質火山灰粒子は，ど のような変質作用を被っているのだろうか。桜島 の火山灰については変質鉱物の記載例が複数あ る。2008 年昭和火口噴火の火山灰には，特徵的 に硫酸カルシウムの複数の相が認められ, 硫黄, 黄鉄鉱も含まれる（宮城ほか, 2010)。一方，松 井・七村（2019）は，2018 年 1 月から 10 月まで の噴火による火山灰を分析し，斜長石などの初生 的な鉱物のほかに，石亳とミョウバン石の存在を 報告している。カオリン鉱物等の層状珪酸塩やシ リカ鉱物は検出されていないか，ごく微弱なピー クが認められるのみである。そのような鉱物が火 山ガラスや初生鉱物を交代するような変質は進ん でいないようである。

桜島の火山灰に認められる硫黄化合物は，火山 ガスに由来すると考えられる。そのような火山ガ スが凝縮したり地下水と混合したりすると，強酸 性熱水を形成し, 溶脱もしくは交代変質作用が生 じる。この変質作用では容易にシリカ鉱物や層状 珪酸塩鉱物が生成する。前節の十勝岳の例はこの ような変質作用によるものである。しかしながら， 桜島の例ではシリカ鉱物やカオリン鉱物が含まれ
ないことから，そのような溶脱・交代反応は進ん でいない。一方，硫酸塩等の硫黄化合物は火山性 流体から直接沈殿する。例えば三宅島 2000 年噴 火の際には，火山ガスから硫酸塩粒子が生成して いるようである。マグマからのガスの蓄積による 爆発的な噴火では，溶脱や交代による珪酸塩変質 よりも硫酸塩の付加作用が卓越するようである。 これらの硫酸塩の生成過程の違いは硫黄同位体組 成に反映されるはずである。水蒸気噴火のメカニ ズムの解明のために，火山灰の硫黄同位体分析は 有用であると考えられる。

図 $3 \mathrm{~d}$ は， $\mathrm{c}$ とは別の鳥海山の完新世テフラ層 に含まれる火山豆石の写真である。火山豆石を構 成する微細火山灰は新鮮な火山岩片や遊離結晶か らなるが，基質部分はそれらとは異なる物質から なる。鳥海山の例では，基質部分は非晶質含鉄ア ルミナ珪酸塩がおもな構成物であり，微細なミョ ウバン石と塩化物が含まれる。桜島の 1983 年 5 月の噴火で類似の火山豆石が生成し，その試料か らは石膏の存在が報告されている（Tomita et al., 1985)。火山豆石を構成する物質は鳥海山と桜島 で異なるものの，いずれも硫酸塩鉱物の存在が特 徵的である。火山豆石の基質は噴火中〜噴火後に 生じることと，硫酸塩（鳥海山では加えて塩化 物）は火山性流体が起源と考えられることから， 火山豆石は噴火に関与した火山性流体の情報を固 体物質として保持している可能性がある。火山ガ スの蓄積による水蒸気噴火の火山灰に火山豆石が 含まれていたならば，その基質中の硫酸塩（およ び塩化物）は噴火の起源となった火山ガスの凝縮 物とみてよいだろう。

\section{VI. ま と め}

日本における「水蒸気噴火」の定義を検討する と，そのメカニズムとして（1）地熱流体の突沸, （2）マグマからの新たな熱による地下水の加熱, それに（3）マグマからのガスの蓄積に分類でき る。水蒸気噴火の英訳として phreatic eruption が一般的に用いられるが，これは上記の 3 つの メカニズムを網羅するわけではない。そこで，本 論文では水蒸気噴火の英訳として， steam-blast 
eruption を採りたい。本論文の後半では $(1) \sim(3)$ の噴火について, その噴出物の特徵を筆者らの 研究を中心にレビューした。（1）は英語の hydrothermal eruptionに相当する。この噴出物は, 変質物に富むことが特徵である。地熱地帯浅所に 由来する噴火も多いが，御獄山 2014 年噴火や秋 田焼山 1997 噴火では，山体深部に発達する複数 の変質帯に由来する多様な変質鉱物組み合わせを もつ変質火山灰が放出されるのを特徵とする。そ の鉱物組み合わせは金属鉱床や地熱地質分野で提 唱されている複成火山直下の変質帯モデルと調和 的である。（2）は英語の phreatic eruptionに相 当するが，強変質を示す噴出物が特徴的である一 方，変質が進んでいない新鮮な溶岩片を含む場合 もみられる。これは頻繁なマグマの貫入とそれに 伴う酸性変質帯の発達を反映していると考えられ る。一方，定常的な酸性熱水系が火口下に発達す る場合，噴出物から新たなマグマ供給の有無を判 断することは困難であり，火山灰に付着した硫黄 の同位体組成分析のような別の分析方法が考えら れる。（3）はブルカノ式噴火が頻発する火山で発 生し, ウルトラブルカノ式噴火と呼べるかも知れ ない。非変質粒子が多く含まれる特徵があり, 変 質鉱物としては，溶脱・交代作用を示すシリカや カオリン鉱物は含まれないが，火山性流体から直 接沈殿する硫酸塩鉱物などの硫黄化合物が認めら れる場合がある。

\section{謝 辞}

本研究を進めるにあたって, 秋田大学早川祐美氏, 遠藤雅宏氏には技術的支援をいただいた。本論文は 日本学術振興会科学技術研究費 (20K05024 おうび 17K01319), 文部科学省事業次世代火山研究・人材育 成総合プロジェクト，拈よび文部科学省補助事業秋田 大学レアメタル等資源ニューフロンティアリーダー養 成プログラムの支援の下で行われた研究をまとめたも のである。

\section{文献}

Angkasa, S.S., Ohba, T., Imura T., Setiawan, I., Mega, F. and Rosana, M.F. (2019): Tephra stratigraphy and ash componentry studies of proximal volcanic products at Mt. Tangkuban Parahu, Indonesia: An insight to Holocene volcanic activity. Indonesian Journal on Geoscience, 6, 235-253.

荒牧重雄 (1996) : 水蒸気噴火. 地学団体研究会編 : 新 版地学事典. 平凡社, 630. [Aramaki, S. (1996): Suijoki-Funka. Cyclopedia of Earth Sciences edited by Association for the Geological Collaboration in Japan, Heibonsha, 630. (in Japanese) ]

Barberi, F., Bertagnini, A., Landi, P. and Principe, C. (1992): A review on phreatic eruptions and their precursors. Journal of Volcanology and Geothermal Research, 52, 231-246.

Browne, P.R.L. and Lawless, J. (2001): Characteristics of hydrothermal eruptions, with examples from New Zealand and elsewhere. Earth-Science Reviews, 52, 299-331.

D'Oriano, C., Bertagnini, A., Cioni, R. and Pompilio, M. (2014): Identifying recycled ash in basaltic eruptions. Scientific Reports, 5851, 1-8.

Ikehata, K. and Maruoka, T. (2016): Sulfur isotopic characteristics of volcanic products from the September 2014 Mount Ontake eruption, Japan. Earth, Planets and Space, 68, doi:10.1186/s40623-0160496-z.

井村 匠・大場 司 -中川光弘 $(2019 a)$ ：噴出物中の 熱水変質鉱物の特徵：十勝岳火山噴出物の例．地質 学雑誌, 125, 203-218. [Imura, T., Ohba, T. and Nakagawa, M. (2019a): Characteristics of hydrothermally altered minerals in volcanic products at Tokachidake volcano, central Hokkaido, Japan. Journal of the Geological Society of Japan, 125, 203-218. (in Japanese with English abstract) ]

Imura, T., Minami, Y., Ohba, T., Matsumoto, A., Arribas, A. and Nakagawa, M. (2019b): Hydrothermal aluminum-phosphate-sulfates in ash from the 2014 hydrothermal eruption at Ontake Volcano, central Honshu, Japan. Minerals, $9(8), 462$.

石原舜三 (1992)：斑岩型鉱床. 地球の資源／地表の 開発。佐々木 昭・石原舜三・関 陽太郎編：岩波 地球科学選書. 岩波書店, 130-134. [Ishihara, S. (1992): Porphyry deposits. Earth resource/development of the surface. in Iwanami Chikyu Kagaku Sensho edited by Sasaki, A., Ishihara, S. and Seki, Y., Iwanami Shoten, 130-134. (in Japanese)*]

伊藤順一 - 川辺禎久 ·吉田明博 - 福山佳之 - 長澤 昭 · 高橋裕史・佐々木耕造 (1997)：澄川温泉水蒸気爆 発噴出物の構成物。地質ニュース, $515,44-48$.

[Itoh, J., Kawanabe, Y., Yoshida, A., Fukuyama, Y., Nagasawa, A., Takahasi H. and Sasaki, K. (1997): Components of hydrothermal eruption deposits at Sumikawa spa, the northern foot of Akita Yakeyama volcano. Chishitsu News, 515, 44-48. (in Japanese) ]

Jaggar, T.A. (1949): Steam blast volcanic eruptions. Special Report, Hawaiian Volcano Observatory, 4.

Lookwood, J.P. and Hazlett, R.W. (2010): An overview of explosive eruptions and their products. in Volcanoes: Global Perspectives, Wiley-Blackwell, 173-222. 
MacDonald, G.A. (1972): Volcanoes. Prentice-Hall, 510 p.

Mastin, L.G. (1995): Thermodynamics of gas and steam-blast eruptions. Bulletin of Volcanology, $\mathbf{5 7}$ 85-98.

松井智彰・七村玲奈 $(2019)$ : 桜島から噴出する火山灰 の構成鉱物に関する研究一火山灰中の変質鉱物から 火山活動を監視するための予備的調査一，鹿児島大 学地震火山地域防災センター平成 30 年度報告書,

111-117. [Matsui, T. and Nanamura, R. (2019): Study on ash component minerals from Sakurajima volcano: Preliminary study of alteration minerals in volcanic ash for monitoring the volcanic activity. The 2018 Report of Research and Education Venter for Natural Hazards (Kagoshima Daigaku Jishin Kazan Chiiki Bosai Senta Heisei 30 Nendo Hokokusho), 111-117. (in Japanese)*]

Minakami, T. (1942): On the distribution of volcanic ejecta (Part I). The distributions of volcanic bombs ejected by the recent explosions of Asama. Bulletin of Earthquake Research Institute, Tokyo, 20, 65-91.

Minami, Y., Imura T., Hayashi, S. and Ohba, T. (2016): Mineralogical study on volcanic ash of the eruption on September 27, 2014 at Ontake volcano, central Japan: Correlation with porphyry copper systems. Earth, Planets and Space, 68, doi:10.1186/ s40623-016-0440-2.

宮城磯治 - 伊藤順一 篠原宏志・鹿児島地方気象台 (2010): 火山灰から見た 2008 年の桜島昭和火口の再 活動過程. 火山，55，21-39. [Miyagi, I., Itoh, J., Shinohara, H. and Kagoshima Observatory, JMA (2010): Re-activation process of Showa volcanic vent at Sakura jima volcano in 2008: Evidence from volcanic ash. Kazan, 55, 21-39. (in Japanese with English abstract) ]

Miyagi, I., Geshi, N., Hamasato, S., Oikawa, T. and Tomiya, A. (2020): Heat source of the 2014 phreatic eruption of Mount Ontake, Japan. Bulletin of Volcanology, 82, 33.

Miwa, T., Geshi, N. and Shinohara, H. (2013): Temporal variation in volcanic ash texture during a vulcanian eruption at the Sakurajima volcano, Japan. Journal of Volcanology and Geothermal Research, 260, 80-89.

水田敏夫・石山大三 (2009): 母岩の変質と鉱床の生成. 資源地質，59，165-180. [Mizuta, T. and Ishiyama, D. (2009): Alteration of host rocks and ore deposition. Shigen Chishitsu, 59, 165-180. (in Japanese)]

野上健治・吉田 稔 (1993): 岩石の酸性変質に伴う 主成分の溶脱過程. 日本化学会誌，3，251-258.

[Nogami, K. and Yoshida, M. (1993): Leaching process of rock forming components through acidic alteration. Journal of the Chemical Society of Japan, 3, 251-258. (in Japanese with English abstract) ]

大場 司 (2011): 熱水変質鉱物に富む火山噴出物一火 山直下熱水系との関係，噴火機構，繰り返し様式. 地 質学雑誌，117，344-356. [Ohba, T. (2011): Hydro- thermal mineral-bearing volcanic products: Relationships with subvolcanic hydrothermal systems, and styles and patterns of their formation. Journal of the Geological Society of Japan, 117, 344-356. (in Japanese with English abstract) ]

Ohba, T. and Kitade, Y. (2005): Subvolcanic hydrothermal systems: Implications from hydrothermal minerals in hydrovolcanic ash. Journal of Volcanology and Geothermal Research, 145, 249-262.

Ohba, T., Taniguchi, H., Miyamoto, T., Hayashi, S. and Hasenaka, T. (2007): Mud plumbing system of an isolated phreatic eruption at Akita Yakeyama volcano, northern Honshu, Japan. Journal of Volcanology and Geothermal Research, 161, 35-46.

及川輝樹 · 大場 司・藤縄明彦 - 佐々木 寿 (2018) : 水蒸気噴火の地質学的研究. 地質学雑誌, 124, 231250. [Oikawa, T., Ohba, T., Fujinawa, A. and Sasaki, H. (2018): Geological study of phreatic eruptions. Journal of the Geological Society of Japan, 124, 231-250. (in Japanese with English abstract) ]

Sillitoe, R.H. (1973): The tops and bottoms of porphyry copper deposits. Economic Geology, 68, 799815.

Sillitoe, R.H. (2010) : Porphyry copper systems. Economic Geology, 105, 3-41.

Stix, J. and de Moor, J.M. (2018): Understanding and forecasting phreatic eruptions driven by magmatic degassing. Earth, Planets and Space, 70, doi: 10.1186/s40623-018-0855-z.

Taddeucci, J., Pompilio, M. and Scarlato, P. (2004): Conduit processes during the July-August 2001 explosive activity of Mt. Etna (Italy): Inferences from glass chemistry and crystal size distribution of ash particles. Journal of Volcanology and Geothermal Research, 137, 33-54.

Takahashi, R. and Yahata, M. (2018): Effects of subvolcanic hydrothermal systems on edifice collapses and phreatic eruptions at Tokachidake volcano, Japan. Journal of Volcanology and Geothermal Research, 352, 117-129.

Tomita, T., Nakai, T., Kobayashi, T. and Oba, N. (1985): Accretionary lapilli formed by the eruption of Sakurajima volcano. Journal of Japanese Association of Mineralogy, Petrology, and Economic Geo$\log y, \mathbf{8 0}, 49-54$.

塚本 斉 (1997)：秋田県澄川温泉における地すべり と水蒸気爆発に伴う土砂災害の発生プロセス。地質 ニュース，515，53-67. [Tsukamoto, H. (1997): Geological process of the 1997 Sumikawa land slide with hydrothermal explosions and debris avalanche Akita Prefecture. Chishitsu News, 515, 53-67. (in Japanese) ]

八幡正弘 - 黒沢邦彦 - 大津 直 - 高橋徹哉・戸間替修一 川森博史・毛利元躬 (1994)：温泉型金鉱床形成期の 変質作用と堆積作用一北海道勢多鉱山を例にして一. 資源地質，44，1-16. [Yahata M., Kurosawa, K., Ohtsu, S., Takahashi, T., Tomagae, S., Kawamori, 
H. and Mori, M. (1994): Hydrothermal alteration and sedimentation at the formative period of a hot spring gold deposit: As an example of the Seta mine in Hokkaido, Japan. Resource Geology, 44, 116. (in Japanese with English abstract) ]

湯原浩三（1997）：噴気爆発の事例. 地熱，34，314-
330. [Yuhara, K. (1997): Review of hydrothermal eruptions. Journal of the Japan Geothermal Energy Association, 34, 314-330. (in Japanese with English abstract) ]

* Title etc. translated by T.O. 